\title{
ANALISA PEMODELAN KUALITAS AIR SUB DAS LESTI DENGAN APLIKASI ARCSWAT 2012
}

\author{
Andika Zuhdi Ramdani ${ }^{1}$, Riyanto Haribowo ${ }^{2}$ \\ ${ }^{1}$ Mahasiswa Program Sarjana Teknik Pengairan Universitas Brawijaya \\ ${ }^{2}$ Dosen Teknik Pengairan Fakultas Teknik Universitas Brawijaya \\ Teknik Pengairan Universitas Brawijaya-Malang, Jawa Timur, Indonesia \\ Jalan MT. Haryono 167 Malang 65145, Indonesia \\ ${ }^{1}$ Email: andikazuhdi0@gmail.com
}

\begin{abstract}
ABSTRAK: Perubahan tata guna lahan dan perilaku manusia yang kurang memerhatikan tentang konservasi alam khususnya di Sub DAS Lesti sebagai daerah studi kualitas air di Waduk Sengguruh semakin memprihatinkan. Analisa kadar nutrien pemicu eutrofikasi perlu dianalisa agar menjadi gambaran kondisi air sehingga menjadi acuan penanganan kedepannya. Penelitian ini bertujuan untuk mengetahui status mutu dan trofik air berdasarkan pemodelan serta penyusunan strategi prioritas penanganannya. Dalam penelitian dilakukan pemodelan ArcSWAT untuk nitrit, nitrat, amonuim, total fosfat, dan total nitrogen untuk tahun 2008-2017 dengan tata guna lahan tahun 2009 dan untuk tahun 2018-2027 dengan tata guna lahan 2016 serta analisa strategi prioritas dengan metode Analytic Hierarchy Process (AHP). Dari analisa status mutu untuk tahun 2008-2017 secara rerata berada pada kelas B dengan kategori tercemar sedang dan status trofiknya oligotrofik. Sedangkan pemodelan tahun 20182027 menunjukkan status mutu kelas B dengan kategori tercemar ringan dengan status trofiknya hipertrofik. Perumusan strategi prioritas metode AHP pada instansi terkait menunjukkan strategi prioritas penanganan yaitu meningkatkan inventarisasi dan identifikasi sumber pencemar air.
\end{abstract}

Kata Kunci: Tata Guna Lahan, Nutrien, Status Mutu, Status Trofik, ArcSWAT, AHP

\begin{abstract}
Changes in land use and human behavior that pay less attention to nature conservation especially in the Lesti Sub-watershed as a study area for water quality in the Sengguruh Reservoir are increasingly alarming. Analysis of nutrient levels of eutrophication triggers needs to be analyzed in order to be a picture of water conditions so that it becomes a reference for future handling. This study aims to determine the quality and trophic status of water based on the modeling and preparation of priority management strategies. In this study ArcSWAT modeling for nitrite, nitrate, ammonium, total phosphate, and total nitrogen for 2008-2017 with land use in 2009 and for the years 2018-2027 with 2016 land use and priority strategy analysis using Analytic Hierarchy Process method (AHP). From the analysis of quality status for the years 2008-2017, the average is in class B with the category of moderate contamination and oligotrophic trophic status. While the modeling in 2018-2027 shows the quality status of class $B$ with a mildly polluted category with hypertrophic trophic status. The formulation of the AHP priority strategy in the relevant agencies shows the priority strategy for handling, namely increasing inventory and identification of water pollutant sources.
\end{abstract}

Keywords: Land Use, Nutrient, Quality Status, Trophic Status, ArcSWAT, AHP

\section{PENDAHULUAN}

Sub DAS Lesti merupakan salah satu DAS yang terdapat di DAS Brantas. DAS lesti merupakan sebagian dari beberapa sub DAS yang menerima pengaruh dari perilaku manusia, baik dari pengelolaan daerah aliran sungai yang buruk atau pun dari pemahaman pengelolaan limbah yang dibuang ke badan air. Perubahan tata guna lahan serta manajemen wilayah DAS akan memberikan pengaruh kepada lingkungan termasuk dalam hal ini ialah sumber daya air (Yamashita et al, 2012), 
sehingga secara tidak langsung memberikan dampak yang pasti kepada kelestarian waduk sengguruh dan sutami yang terdapat di outlet DAS.

Sebagaimana menurut Effendi (2003) bahwa nutrien berupa nitrogen dan total fosfat merupakan nutrien yang sangat melimpah keberadaannya di Alam ini. Unsur nitrogen merupakan unsur yang keberadaannya terbesar di biosfer $(78 \%$ gas di atmosfer adalah nitrogen). Sedangkan fosfor merupakan unsur dasar yang sangat dibutuhkan oleh tumbuhan tingkat tinggi dan alga, sehingga keberadaan dari fosfor memberikan pengaruh pada produktivitas perairan. Fosfat terdapat dalam air alam atau air limbah sebagai senyawa berbentuk ortofosfat, polifosfat dan fosfat organis. Pada area pertanian yang menggunakan pupuk secara intens merupakan sumber utama fosfor pada wilayah perairan yang terbawa oleh limpasan permukaan serta aliran sungai. Kadar nitrogen dan fosfat yang mencapai kadar tertentu dapat diklasifikasikan sebagai kondisi trofik dimana kondisi ini menandakan terjadinya kelimpahan nutrien pada perairan sehingga dapat memberikan dampak berupa fenomena algae blooming (Riyanto et al, 2017).

Soil Water Assessment Tool (SWAT) merupakan sebuah model hidrologi yang berskala daerah aliran sungai yang dimanfaatkan untuk mengetahui respon suatu daerah aliran sungai terhadap segala bentuk perlakuan dalam daerah aliran sungai. SWAT dikembangkan oleh USDA Agricultural Research Service (Hidayat dkk, 2016). SWAT membutuhkan data digital seperti data sebaran jenis tanah, kemiringan lereng, dan tata guna lahan (Cesar Perez, 2017). DAS yang dimodelkan dibagi secara spasial menjadi sub DAS menggunakan data dalam bentuk Digital Elevation Model (DEM) (Cheng-Zhi, 2017). Setelah itu pengelolaan berikutnya ialah berbentuk Hydrologic Response Units (HRU's) yang dimana HRU merupakan bentuk digital yang berupa kombinasi dari data kemiringan lereng, tata guna lahan, serta sebaran jenis tanah (Urooj et al, 2013).

Berdasarkan deskripsi kondisi Sub DAS Lesti saat ini, maka oleh karena itu analisa tentang kualitas air dan status trofik di DAS Lesti dengan memanfaatkan piranti sistem informasi geografis atau SIG berupa ekstensi dari Arcmap Soil And Water Assesment Tools atau ArcSWAT 2012 akan sangat penting untuk memberikan informasi geografis dengan memasukkan beberapa parameter yang lebih kompleks serta pemodelan untuk mem-prediksi kondisi untuk periode berikutnya serta menyusun strategi penang-gulangan pencemaran air di DAS Lesti sebagai upaya konservasi kelestarian alam terutama kualitas dan kuantitas air.

Tujuan dari studi ini adalah untuk mengetahui beban pencemaran nutrien di Sub DAS Lesti, mengetahui status mutu, status trofik, serta menyusun strategi prioritas penanganannya sehingga penelitian ini dapat menjadi upaya pencegahan masalah pencemaran dan konservasi lingkungan di Sub DAS Lesti serta mampu memberikan informasi kepada pemerintah setempat dalam pengambilan keputusan penanganannya.

\section{METODOLOGI STUDI}

Lokasi studi berada di Sub DAS Lesti yang menjadi penyuplai berbagai masukan zat, materi, atau nutrien menuju ke Waduk Sengguruh. Berikut disajikan pada Gambar 1.

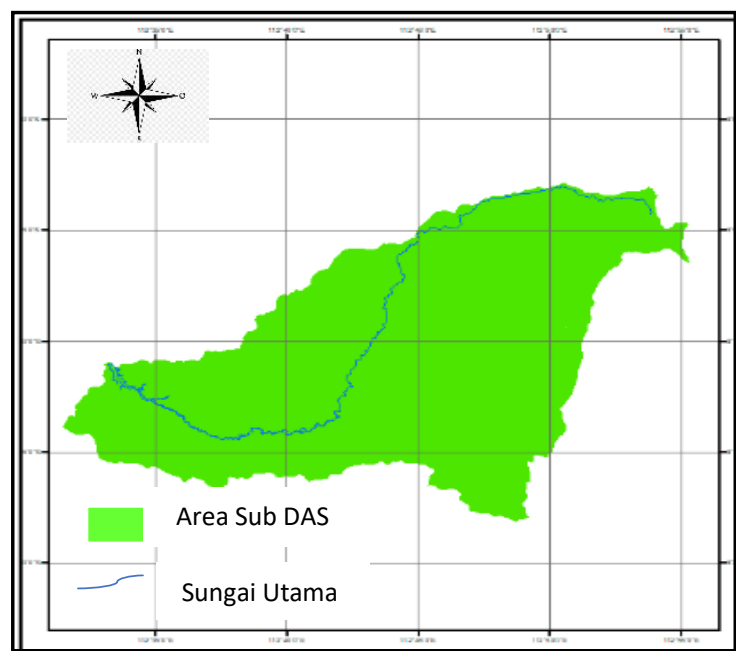

Gambar 1. Peta Sub DAS Lesti

Sumber: BPDAS Brantas-Sampean

Pada Gambar 1 dijelaskan tentang gambaran dari Sub DAS Lesti dengan warna hijau merupakan area sub DAS dan garis biru merupakan sungai uatama. Untuk deskripsi DAS Lesti, secara geografis Sub DAS Lesti berbentuk memanjang terletak diantara $8^{\circ} 02^{\prime} 50^{\prime \prime}-8^{\circ} 12^{\prime} 10^{\prime \prime}$ Lintang Selatan dan $112^{\circ} 42^{\prime} 58^{\prime \prime}$ sampai $112^{\circ} 56^{\prime} 21^{\prime \prime}$ Bujur Timur. Secara administratif termasuk ke dalam wilayah Kabupaten Malang. Sub DAS Lesti bagian Hilir ini berada di 9 kecamatan di Kabupaten Malang antara lain: Sumbermanjingwetan, Turen, Wajak, Bululawang, Gondanglegi, Pagelaran, Gedang- 
an, Bantur dan Pagak. Secara tata guna lahan, Sub DAS lesti terdiri dari kawasan pertanian, hutan, pemukiman, tegalan, perkebunan, semak belukar, dan waduk. Setelah dilakukan analisa batas DAS, diperoleh luas Sub DAS Lesti 60885.512 Ha, 31 outlets sub DAS beserta jaringan sungainya.

\section{Data - Data Yang Diperlukan}

Dalam penelitian ini dibutuhkan beberapa data-data sebagai berikut :

\section{Data Primer}

Data hasil pengisian kuisioner oleh 5 (lima) pesponden yang telah memenuhi kriteria di BPDAS Brantas, Dinas PUSDA dan Dinas Lingkungan Hidup Kab. Malang

\section{Data Sekunder}

A. Peta digital yang diperoleh dari BPDAS Brantas, meliputi :

1. Data topografi

2. Data tata guna lahan

3. Data sebaran jenis tanah

B. Data hidrologi yang diperoleh dari Dinas Pekerjaan Umum Sumber Daya Air Kabupaten Malang, meliputi :

1.Data curah hujan harian di Sub DAS Lesti tahun 2008-2017

\section{Data Debit tahun 2008-2017}

C. Data pengukuran kualitas air yang diperoleh dari Perum Jasa Tirta I untuk tahun 2008-2017

D. Data Jenis Pupuk, diperoleh dari Dinas Tanaman Pangan, Holtikultura dan Perkebunan Kabupaten Malang.

\section{Analisa Hidrologi}

Analisa hidrologi yang digunakan untuk menguji kualitas data hujan yang diperoleh adalah dengan menggunakan uji ketidakadaan trend, uji stasioner, dan uji persistensi.

\section{Uji Ketidakadaaan Trend}

Beberapa metode statistika yang digunakan dalam menguji ketidakadaaan trend dalam penelitian ini diantaranya:

- Korelasi Peringkat Metode Spearman

Sebuah trend dapat dipandang sebagai korelasi antara waktu dengan variat suatu variabel hidrologi. Oleh karena itu koefisien korelasinya dapat digunakan untuk mengetahui ketidakadan trend dari suatu deret berkala (Soewarno, 1996).
Metode korelasi Spearman dapat digunakan untuk menentukan ketidakadaan trend dengan rumus sebagai berikut:

$$
\begin{gathered}
\mathrm{KP}=1-\frac{\sum_{i=1}^{\mathrm{n}}(d t)^{\mathrm{z}}}{\mathrm{n}^{\mathrm{g}}-\mathrm{n}} \\
\mathrm{t}=\mathrm{KP}\left[\frac{\mathrm{n}-2}{1-\mathrm{KP}^{\mathrm{a}}}\right]^{1 / 2}
\end{gathered}
$$

Keterangan:

KP : Koefisien korelasi peringkat dari Spearman

$\mathrm{N}$ : Jumlah data

Tt : Peringkat dari waktu

Rt : Peringkat dari variabel hidrologi dalam deret berkala.

$\mathrm{T}$ : Nilai distribusi t, pada derajat kebebasan (n-2) untuk derjat kepercayaan tertentu (umumnya $5 \%)$.

\section{- Uji Mann-Whitney}

Uji Mann-Whitney dipakai untuk menguji apakah dari dua kelompok data yang tidak berpasangan berasal dari populasi yang sama atau tidak (Soewarno, 1996).

Tahapan pengujiannya adalah:

1. Menggabungkan dua kelompok data.

2. memberikan peringkat data dari yang bernilai paling kecil sampai paling besar.

3. Menghitung jumlah peringkat dari hasil pemeringkatan kelompok.

4. Menghitung parameter statistik:

$\mathrm{U}_{1}=\mathrm{N}_{1} \mathrm{~N}_{2}+\frac{\mathrm{N} 1}{2}\left(\mathrm{~N}_{1}-1\right)-\mathrm{Rm}$

$\mathrm{U}_{2}=\mathrm{N}_{1} \mathrm{~N}_{2}-\mathrm{U}_{1}$

Keterangan:

$\mathrm{U}_{1}, \mathrm{U}_{2}=$ parameter statistik

$\mathrm{N}_{1} \quad=$ jumlah data kelompok $\mathrm{A}$

$\mathrm{N}_{2} \quad=$ jumlah data kelompok $\mathrm{B}$

$\mathrm{Rm}=$ jumlah nilai peringkat dari rangkaian data kelompok $\mathrm{A}$

5. Memilih nilai $U_{1}$ atau $U_{2}$ yang memiliki nilai terkecil yang kemudian mewakili nilai $U$ pada analisa berikutnya.

6. menghitung uji Mann - Whitney, sebagai nilai Z:

$$
Z=\frac{\frac{\dot{U}-\left(\mathrm{N}_{1} \mathrm{Na}_{2}\right)}{\mathrm{s}}}{\left[\frac{1}{12}[\mathrm{~N} 1 N 2(N 1+N 2+1)]\right]^{1 / 2}}
$$

7. Keputusan:

Dari hasil analisa diperoleh nilai $\mathrm{Z}$ hitung dan $Z$ tabel pada pengujian dua sisi. Jika nilai $\mathrm{Z}<\mathrm{Zc}$ maka hipotesisi nol dapat diterima, sedangkan jika sebaliknya maka ditolak. 


\section{Uji Stasioner}

Analisa hidrologi berikutnya ialah dilakukan uji stasioner. Apabila pada uji ketidakadaaan trend maka analisa berikutnya ialah dilakukan uji stasioner dengan tujuan untuk mengetahui kestabilan nilai varian dan rerata dari deret berkala. Uji kestabilan nilai varian dapat dilakukan dengan uji-F, sedangkan untuk uji kestabilan nilai rerata dilakukan dengan menggunakan uji-t (Soewarno, 1996).

\section{Uji Kestabilan Varian}

Berdasarkan Uji-F, digunakan persamaan:

$$
F=\frac{n 1 S 1(n 2-1)}{n 2(n 1-1) S 2^{2}}
$$

\section{Keterangan:}

n1 : jumlah data pada kelompok I

n2 : jumlah data pada kelompok II

S1 : Standar deviasi pada kelompok I

S2 : Standar deviasi pada kelompok II

Pada derajat kebebasan $\mathrm{dk} 1=\mathrm{n} 1-1$ dan $\mathrm{dk} 2=\mathrm{n} 2-1$ dengan derajat kepercayaan 5\%, maka dapat dilihat nilai $\mathrm{F}$ berdasarkan pada tabel. Jika nilai $\mathrm{F}$ analisa ternyata lebih besar dari $\mathrm{F}$ yang ada di tabel, maka nilai variannya stabil (Soewarno, 1996).

\section{Uji Kestabilan Nilai Rerata}

$$
\begin{aligned}
& t=\frac{\text { Berdasarkan Uji-t dengan }}{\sigma\left(\frac{1}{n 1}+\frac{1}{n 2}\right)^{1 / 2}} \\
& \sigma=\left(\frac{n 1 S 1^{2}+n 2 S 2^{2}}{n 1+n 2-2}\right)^{1 / 2}
\end{aligned}
$$

Untuk derajat kebebasan $\mathrm{dk}=\mathrm{n} 1+\mathrm{n} 2-2$ dengan derajat kepercayaan 0,025 pada uji dua sisi maka berikutnya kita dapat mengetahui nilai $\mathrm{t}$ tabel. Jika nilai $\mathrm{t}$ analisa lebih besar dari t tabel, maka hipotesis nol diterima dan nilai rerata adalah stabil (Soewarno, 1996).

\section{Uji Persistensi}

Analisa hidrologi berikutnya adalah uji persistensi. Persistensi diartikan sebagai ketidaktergantungan antar nilai dalam suatu deret berkala. Langkah pengujian persistensi dilakukan dengan mengetahui koefisien korelasi serialnya. Metode yang digunakan untuk mengetahui koefisien korelasi serial adalah Metode Spearman (Soewarno 1996).

Koefisien korelasi serial metode Spearman dapat ditentukan dengan rumus sebagai berikut:

$$
\begin{aligned}
& \mathrm{KS}=1-\frac{\sum_{\mathrm{i}=1}^{\mathrm{n}}(\mathrm{di})^{2}}{\mathrm{~m}^{3}-\mathrm{m}} \\
& \mathrm{t}=\mathrm{KP}\left[\frac{\mathrm{m}-2}{1-\mathrm{KS}^{2}}\right]^{1 / 2}
\end{aligned}
$$

Keterangan :

$$
\begin{aligned}
& \mathrm{KS}: \text { koefisien korelasi serial } \\
& \mathrm{m}: \mathrm{N}-1 \\
& \mathrm{n}: \text { jumlah data } \\
& \mathrm{di}
\end{aligned}
$$

Berdasarkan uji satu sisi, pada derajat kepercayaan $5 \%$, dengan derajat kebebasan $\mathrm{m}$ 2 , maka diperoleh nilai $\mathrm{t}$ tabel. Jika $\mathrm{t}$ hitung < dari $\mathrm{t}$ tabel, maka disimpulkan bahwa data adalah independen atau tidak menunjukkan adanya persistensi (Soewarno, 1996).

\section{Soil Water Assessment Tool (SWAT)}

SWAT merupakan sebuah sistem pemodelan berbasis daerah aliran sungai yang dimana pemanfaatannya digunakan untuk mengetahui respon dari suatu daerah aliran sungai terhadap manajemen lahan. SWAT dikembangkan oleh badan USDA Agricultural Research Service (Hidayat dkk, 2016). Model SWAT dilakukan berdasarkan hasil pemodelan pada periode kurang lebih 30 tahun pada berbagai praktek manajemen lahan, kondisi, karakter serta waktu yang cukup lama (Hidayat dkk, 2016). SWAT menggunakan data curah hujan, tata una lahan sebaran jenis tanah, kemiringan lereng berbasis data spasial guna untuk mengetahui pendugaan besaran debit, sedimen, atau sebaran nutrien akibat suatu manajemen lahan di suatu daerah aliran sungai. Data suatu daerah aliran studi yang digunakan dalam analisa ArcSWAT ialah dalam bentuk Digital Elevation Model (DEM). Kemudian dalam analisa suatu daerah aliran sungai akan dibagi kembali kedalam bentuk Hydrology Response Units atau HRU dengan komponen tata guna laan, kemiringan lereng serta sebaran jenis tanahnya (Hidayat dkk, 2016). Dalam penerapannya, SWAT banyak digunakan dalam berbagai analisa atau pemodelan respon suatu DAS akibat mana-jemen lahan atau perubahan tata guna lahan dengan outupun berupa 
konservasi tanah dan air dan penentuan lokasi check dam (Hidayat dkk, 2016).

\section{Kalibrasi}

Proses kalibrasi dilakukan agar mengetahui perbandingan antara nilai hasil model dengan nilai hasil observasi atau nilai pengukuran langsung dilapangan. Kalibrasi dalam pemodelan ArcSWAT dilakukan dengan mengubah beberapa parameter-parameter yang memiliki nilai sensitivitas terhadap nilai pemodelan. Dalam kalibrasi ini sedapat mungkin kita dapat menentukan beberapa parameter dari karaktristik daerah aliran sungai lokasi penelitian kita diantaranya nilai seperti nilai CN (Curve Number), GW (Ground Water), atau nilai baseflow memiliki sensitifitas tinggi dengan harapan setelah menemukan parameter yang sesuai maka perbandingan antara nilai model dengan hasil observasi lapangan memiliki selisih yang lebih kecil. Acuan dalam kalibrasi yang biasa digunakan ialah nilai debit pada Automatic Water Level Recorder atau AWLR di sungai lokasi studi (Suhartanto, 2008).

\section{Analisa Mutu Air Metode Storet}

Penentuan status mutu air menggunakan metode storet dilakukan berdasarkan Keputusan Menteri Lingkungan Hidup 115 Tahun 2003. Metode storet diterapkan pada analisa mutu air dengan perbandingan antara data kualitas air yang telah dianalisa dengan baku mutu air sesuai pemanfaatannya.

Setelah membandingkan kualitas dengan baku mutu sesuai peruntukkannya maka dilakukan penilaian berdasarkan sistem penilaian dari United State - Environmental Protection Agency (US-EPA) dengan mengklasifikasikan mutu air dengan empat kelas menurut Keputusan menteri Lingkunga Hidup No. 115 Tahun 2003.

Adapun langkah - langkah untuk penentuan status mutu air menggunakan metode storet adalah sebagai berikut:

1. Melakukan pengumpulan data kualitas dan debit air secara periodik sehingga dapat membentuk data dari waktu ke waktu (time series data).

2. Melakukan perbandingan data hasil pengukuran dengan nilai baku mutu yang sesuai kelasnya.

3. Jika hasil dari perbandingan data pengukuran kualitas air dengan baku mutu menunjukkan bahwa kualitas air bedara dibawah baku mutu maka diberikan skor 0 .

4. Jika hasil perbandingan pengukuran kualitas air dan baku mutu menunjukkan bahwa kualitas air berada di atas baku mutu maka penilaian dilakukan berdasarkan tabel penentuan sistem nilai untuk menentukan status mutu airnya.

5. Nilai negatif dari hasil penilaian kemudian dijumlah dan hasilnya disesuaikan dengan sistem penilaian USEPA.

\section{Metode Penentuan Status Trofik}

Status trofik ialah suatu kondisi wilayah oerairan dimana terjadinya proses produktivitas berlebihan akibat kadar nitrogen dan fosfor yang sangat tinggi sehingga jika terjadi secara kontinyu dapat berakibat pada fenomena algae blooming.

Eutrofikasi diklasifikasikan menjadi empat kategori status trofik (PerMNLH Nomor 28 tahun 2009) ialah oligotrofik, mesotrofik, eutrofik, dan hipereutrofik.

Berikutnya mengenai kriteria status trofik danau berdasarkan Peraturan Kementerian Lingkungan Hidup Nomor 28 tahun 2009 terdapat pada tabel berikut ini:

Tabel 1. Kriteria Status Trofik

\begin{tabular}{||c|c|c|c|c||}
\hline Status Trofik & $\begin{array}{c}\text { Kadar Rata- } \\
\text { rata Total-N } \\
(\boldsymbol{\mu g} / \mathbf{l})\end{array}$ & $\begin{array}{c}\text { Kadar Rata- } \\
\text { rata Total-P } \\
(\boldsymbol{\mu g} / \mathbf{l})\end{array}$ & $\begin{array}{c}\text { Kadar } \\
\text { Rata-rata } \\
\text { Khlorofil a } \\
(\boldsymbol{\mu g} / \mathbf{l})\end{array}$ & $\begin{array}{l}\text { Kecerahan } \\
\text { Rata-rata } \\
(\mathbf{m})\end{array}$ \\
\hline Oligotrof & $\leq 650$ & $<10$ & $<2.0$ & $\geq 10$ \\
\hline Mesotrof & $\leq 750$ & $<30$ & $<5.0$ & $\geq 4$ \\
\hline Eutrof & $\leq 1900$ & $<100$ & $<15$ & $\geq 2,5$ \\
\hline Hipereutrof & $>1900$ & $\geq 100$ & $\geq 200$ & $<2,5$ \\
\hline
\end{tabular}

Sumber: Kementrian Lingkungan Hidup, 2009

\section{Pencemaran Air}

Pencemaran air adalah turunnya mutu air yang diakibatkan oleh masukknya suatu zat, energi, materi, makhluk hidup atau komponen lainnya ke dalam perairan sehingga peruntukkan dari air itu pun berkurang. (Kementerian Lingkungan Hidup, 2010). Dalam penelitian ini akan dianalisa tentang pencemaran air yang disebabkan oleh parameter -parameter nutrien nitrat, nitrit, amonium, total nitrogen dan fosfat.

\section{Analytic Hierarchy Process}

Metode yang dilakukan untuk menentukan strategi prioritas ialah dengan metode AHP. 
Metode AHP dilakukan dengan memberikan responden kuisioner yang berisikan skala perbandingan kepentingan atau keputusan. Skala perbandingan disesuaikan dengan skala pada metode AHP. Dari hasil pengisian kuisioner skala perbandingan tersebut yang kemudian ditransformasikan dalam bentuk matriks perbandingan berpasangan untuk menganalisis numeriknya. Perbandingan antar alternatif untuk sub sistem hirarki itu dapat dibuat dalam bentuk matriks $\mathrm{n} \times \mathrm{n}$, seperti pada Tabel Matriks Perbandingan Berpasangan dan diisi sesuai skala kepentingan pada Tabel Skala Penilaian Perbandingan Berpasangan pada buku Pengambilan Keputusan Bagi Para Pemimpin, Proses Hirarki Analitik untuk Pengambilan Keputusan dalam Situasi yang Kompleks Oleh Saaty (1993).

Penentuan konsistensi dari matriks itu sendiri didasarkan atas nilai dari eigen value maksimum yang diperoleh dengan rumus sebagai berikut:

$\mathrm{CI}=\lambda \max -n / n-1$

Keterangan:

$\begin{array}{ll}\mathrm{CI} & =\underset{\text { Rasio penyimpangan (deviasi) }}{\text { konsistensi (consistency indeks) }} \\ \lambda \max & =\begin{array}{c}\text { Nilai eigen terbesar dari matriks } \\ \text { berordo } \mathrm{n}\end{array} \\ \mathrm{n} & =\text { Orde matriks }\end{array}$

Jika dari hasill analisa matrik nilai CI menunjukkan nol, maka matriks pairwise comparison tersebut dianggap konsisten. Namun jika hasil CI diatas nol, maka batas toleransi ketidakkonsistenan (inconsistency) yang telah ditetapkan oleh Thomas L. Saaty ditentukan dengan meganalisa nilai rasio konsistensi (CR), yaitu perbandingan indeks konsistensi dengan nilai random indeks (RI). Rasio konsistensi dapat dirumuskan pada rumus sebagai berikut:

$\mathrm{CR}=\mathrm{CI} / \mathrm{RI}$

Keterangan:

$\mathrm{CR}=$ Rasio Konsistensi

$\mathrm{RI}=$ Indeks Random

Jika matriks perbandingan berpasangan (pairwise comparison) dengan nilai $\mathrm{CR}$ lebih kecil dari atau maksimal senilai 0,100 maka ketidakkonsistenan pendapat pengambilan keputusan dapat ditolerir.
Dari penelitian sebelumya yang dilakukan oleh Arbi (2007) tentang dampak perubahan tata guna lahan terhadap kualitas air di sub DAS Lesti menggunakan aplikasi AVSWAT 2000 menjelaskan tentang hasil pemodelan kualitas air berdasarkan perubahan tata guna lahan terhadap kadar nutriennya yaitu nitrat, nitrit, amonia, dan total fosfat untuk tahun sebelum 2007 dan prediksi untuk tahun berikutnya setelah kalibrasi. Sedangkan pada penelitian ini menindaklanjuti dengan melakukan pemodelan dengan aplikasi ArcSWAT 2012 tahun 2008-2017, prediksi tahun 2018-2027 untuk nutrient $\mathrm{NO}_{2}, \mathrm{NO}_{3}$, $\mathrm{NH}_{4}$, total $\mathrm{P}$ dan total $\mathrm{N}$, menganalisa status mutu dan trofik, serta menganalisa strategi prioritas dengan metode AHP.

Penelitian ini bertujuan untuk mengetahui kadar dan sebaran nutrient $\mathrm{NO}_{2}, \mathrm{NO}_{3}, \mathrm{NH}_{4}$, total $\mathrm{P}$ dan total $\mathrm{N}$, untuk tahun 2008-2017 dan 2018-2027, menganalisa status mutu dan trofik serta strategi penanganannya sehingga mampu memberikan gambaran umum kondisi di Sub DAS Lesti serta masukan strategi prioritas kepada pihak yang berwenang dalam penanganan pencemaran lingkungan.

\section{HASIL DAN PEMBAHASAN Hasil Analisa Peta HRU Sub DAS Lesti}

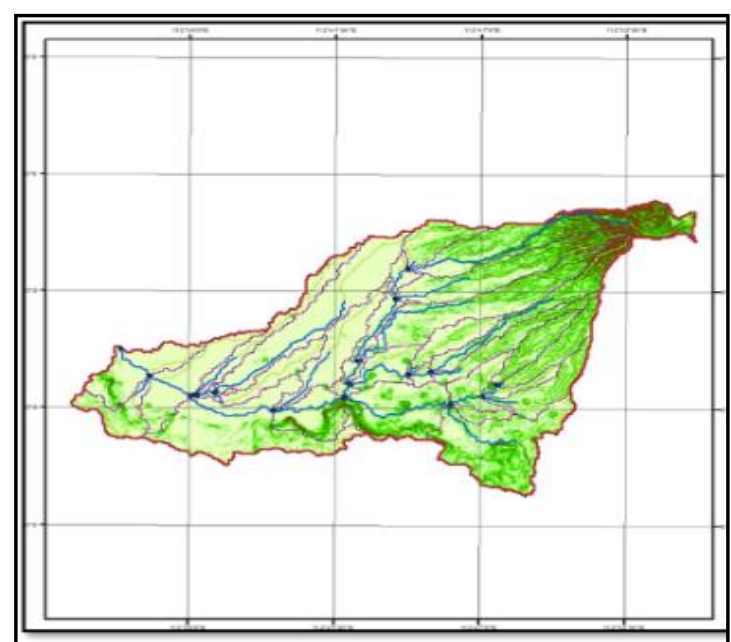

Gambar 2. Peta HRU Sub DAS Lesti

Sumber: Pengolahan ArcSWAT, 2018

Program permodelan ArcSWAT membutuhkan informasi-informasi mengenai data berupa peta tata guna lahan, peta jenis tanah dan kemiringan lereng daerah yang diteliti. ArcSWAT mempunyai menu HRU analysis, yang di dalamnya ada tools Land Use/Soil/Slope Definition. Tools ini berfungsi untuk mengakses dialog box untuk memasukkan peta tata guna lahan, peta jenis 
tanah dan kemiringan lereng yang akan menguhubungkan peta ke SWAT database kemudian akan mengoverlay ketiga peta tersebut membentuk HRU (Hidrology Responsive Unit).

Dari Gambar 2 dijelaskan tentang deskripsi DAS Lesti hasil analisa ArcSWAT dengan meng-overlay-kan data sebaran jenis tanah, kemiringan lereng, serta tata guna lahan. Dari gambar tersebut didominasi oleh dataran rendah, sedangkan dibagian Timur Laut yang merupakan hulu DAS memiliki kemiringan lereng yang curam kemudian terus menuju ke Barat yang merupakan hilir DAS yang didominasi dataran rendah dan termasuk ke area genangan Waduk Sengguruh.

\section{Analisa Hidrologi}

Tabel 2. Curah Hujan Harian Maksimum Tahunan 2008-2017

\begin{tabular}{ccccccc}
\hline & & \multicolumn{5}{c}{ Stasiun Hujan } \\
\cline { 3 - 7 } N & Tahun & Pampit & Pagak & $\begin{array}{c}\text { Ponco } \\
\text { kusumo }\end{array}$ & $\begin{array}{c}\text { Tumpuk } \\
\text { Renteng }\end{array}$ & Turen \\
\hline 1 & 2008 & 117.0 & 108.0 & 150.0 & 110.0 & 127.0 \\
2 & 2009 & 106.0 & 77.0 & 85.0 & 104.0 & 68.0 \\
3 & 2010 & 108.0 & 88.0 & 94.0 & 134.0 & 100.0 \\
4 & 2011 & 89.0 & 113.0 & 79.0 & 105.0 & 57.0 \\
5 & 2012 & 109.0 & 115.0 & 110.0 & 116.0 & 115.0 \\
6 & 2013 & 79.0 & 90.0 & 115.0 & 99.0 & 102.0 \\
7 & 2014 & 74.0 & 105.0 & 83.0 & 78.0 & 63.0 \\
8 & 2015 & 89.0 & 136.0 & 75.0 & 80.0 & 83.0 \\
9 & 2016 & 147.0 & 104.0 & 115.0 & 86.0 & 88.0 \\
1 & 2017 & 103.0 & 84.0 & 85.0 & 86.0 & 74.0 \\
0 & & &
\end{tabular}

Sumber: Dinas PUSDA Kab. Malang

Dari Tabel 2 dijelaskan tentang curah harian maksimum tahunan tahun 2008-2017 di Sub DAS Lesti pada stasiun penakar curah hujan Dampit, Pagak, Poncokusumo, TumpukRenteng, dan Turen. Penakar curah hujan ini tersebar di wilayah Sub Daerah Aliran Sungai Lesti. Terlihat curah hujan tinggi terutama pada Stasiun Dampit dan pada tahun 2008. Sehingga dapat diperkirakan kawasan di alat penakar Dampit akan mengalami pengaruh limpasan yang lebih tinggi dari kawasan lainnya. Curah hujan harian maksimum tahunan ini kemudian dibutuhkan untuk analisa statistika data hujan.

Tabel 3. Rekapitulasi Analisa Hidrologi

\begin{tabular}{cccccc}
\hline \multirow{2}{*}{ Pos Hujan } & \multicolumn{5}{c}{ Jenis Pengujian } \\
\cline { 2 - 6 } & $\begin{array}{c}\text { Korelasi } \\
\text { Spearman }\end{array}$ & $\begin{array}{c}\text { Mann - } \\
\text { Whitney }\end{array}$ & $\begin{array}{c}\text { Stasioner } \\
\text { Uji F }\end{array}$ & $\begin{array}{c}\text { Stasioner } \\
\text { Uji t }\end{array}$ & Persistensi \\
\hline Dampit & Diterima & Diterima & Diterima & Diterima & Diterima \\
Pagak & Diterima & Diterima & Diterima & Diterima & Diterima \\
Poncokusumo & Diterima & Diterima & Diterima & Diterima & Ditolak \\
$\begin{array}{c}\text { Tumpung- } \\
\text { Renteng }\end{array}$ & Diterima & Diterima & Diterima & Ditolak & Diterima \\
Turen & Diterima & Diterima & Diterima & Diterima & Ditolak
\end{tabular}

Sumber : Hasil Analisa, 2018
Dari Tabel 3 dijelaskan rekapitulasi hasil dari semua uji data hujan yang telah dilakukan. Setelah dilakukan Uji Korelasi Spearman dan Mann-Whitey yang bertujuan untuk mengetahui ketidakadaan trend, Uji F yang bertujuan menguji kestabilan varian, uji $\mathrm{t}$ untuk menguji kestabilan nilai rerata, dan terakhir uji persistensi yang bertujuan untuk mengetahui data independent atau tidak, maka dari semua uji yang telah dilakukan menunjukkan rerata kualitas yang baik.

\section{Simulasi Sebelum Kalibrasi Dengan TGL} Tahun 2009

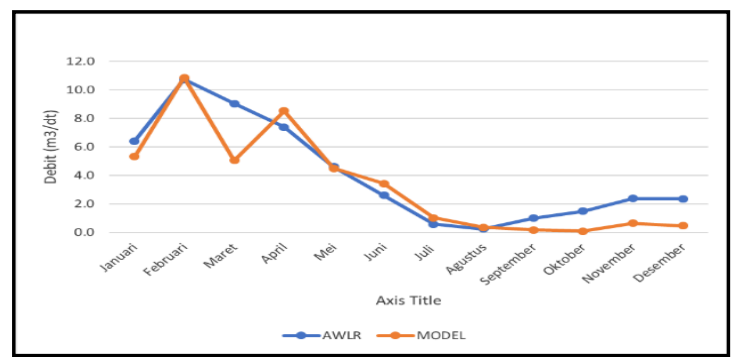

Gambar 3. Grafik hasil simulasi debit ArcSWAT sebelum kalibrasi tahun 2009

Sumber: Hasil Analisa, 2018

\section{Simulasi Sebelum Kalibrasi Dengan TGL} Tahun 2016

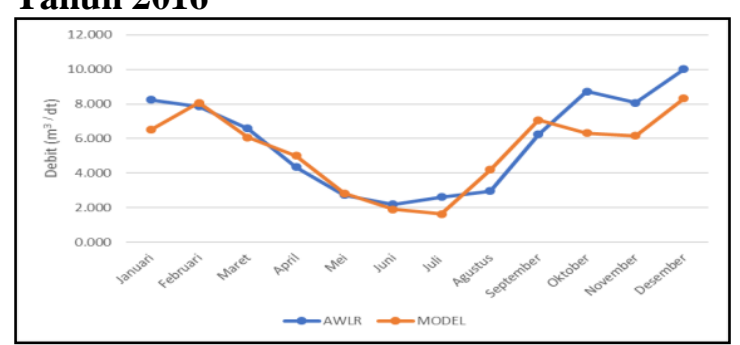

Gambar 4. Grafik hasil simulasi debit ArcSWAT sebelum kalibrasi tahun 2016

Sumber: Hasil Analisa, 2018

Berdasarkan Gambar 3 dijelaskan gambaran data debit AWLR dan model sebelum dilakukannya kalibrasi. Pada Gambar 3 terlihat selisih grafik antara data debit AWLR dan model untuk beberapa bulan masih terlihat jauh. Serupa dengan penjelasan Gambar 3, pada Gambar 4 didapatkan selisih data debit AWLR dan model yang besar. Hal tersebut bisa terjadi karena adanya beberapa parameter database, baik itu pengaruh dari kondisi tanah (.sol), air tanah (.gw), manajemen lahan (.mgt), dan Hydrologic Responce Unit (.HRU) yang belum sesuai dengan kondisi lapangan. 
Berdasarkan permasalahan di atas perlu dilakukan kalibrasi data dengan mengubah, mengurangi, atau menambahkan beberapa parameter yang memiliki pengaruh pada model berdasarkan referensi penelitian-penelitian sebelumnya.

\section{Parameter - Parameter Kalibrasi}

Tabel 4. Parameter Input Pada Tahun Kalibrasi Tahun 2009

\begin{tabular}{cclccc}
\hline No & Parameter & \multicolumn{1}{c}{ Deskripsi } & $\begin{array}{c}\text { Lower } \\
\text { Bound }\end{array}$ & $\begin{array}{c}\text { Upper } \\
\text { Bound }\end{array}$ & $\begin{array}{c}\text { Nilai } \\
\text { Kalibrasi }\end{array}$ \\
\hline 1 & Cn2 & $\begin{array}{l}\text { SCS Curve Number } \\
\text { Kapasitas air yang }\end{array}$ & 35 & 98 & 98 \\
2 & Sol_Awc & $\begin{array}{l}\text { tersedia dalam tanah } \\
\text { Faktor pergantian }\end{array}$ & 0 & 1 & 0.001 \\
4 & Esco & $\begin{array}{l}\text { evaporasi air tanah } \\
\text { Surface runoff lag } \\
\text { time }\end{array}$ & 0 & 1 & 0.9 \\
5 & Surlag & $\begin{array}{l}\text { Masa jeda air dalam } \\
\text { tanah kembali ke } \\
\text { sungai }\end{array}$ & 1 & 24 & 24 \\
6 & Gw_Delay & $\begin{array}{l}\text { Faktor Perkolasi Air } \\
\text { Tanah }\end{array}$ & 0 & 500 & 1 \\
7 & Rchrg_dp & $\begin{array}{l}\text { Nilai Alpha aliran } \\
\text { dasar }\end{array}$ & 0 & 1 & 0.1 \\
\hline
\end{tabular}

Sumber: Hasil Analisa, 2018

Tabel 5. Parameter Input Pada Tahun Kalibrasi Tahun 2016

\begin{tabular}{cccccc}
\hline No & Parameter & \multicolumn{1}{c}{ Deskripsi } & $\begin{array}{c}\text { Lower } \\
\text { Bound }\end{array}$ & $\begin{array}{c}\text { Upper } \\
\text { Bound }\end{array}$ & $\begin{array}{c}\text { Nilai } \\
\text { Kalibrasi }\end{array}$ \\
\hline 1 & Cn2 & $\begin{array}{l}\text { SCS Curve Number } \\
\text { Kapasitas air yang }\end{array}$ & 35 & 98 & 98 \\
2 & Sol_Awc & $\begin{array}{l}\text { tersedia dalam tanah } \\
\text { Faktor pergantian } \\
\text { evaporasi air tanah }\end{array}$ & 0 & 1 & 0.21 \\
4 & Esco & $\begin{array}{l}\text { Surface runoff lag } \\
\text { time }\end{array}$ & 1 & 24 & 24 \\
5 & Surlag & $\begin{array}{l}\text { Masa jeda air dalam } \\
\text { tanah kembali ke } \\
\text { sungai }\end{array}$ & 0 & 500 & 1 \\
6 & Gw_Delay & $\begin{array}{l}\text { Faktor Perkolasi Air } \\
\text { Tanah }\end{array}$ & 0 & 1 & 0.5 \\
7 & Alpha_Bf & $\begin{array}{l}\text { Nilai Alpha aliran } \\
\text { dasar }\end{array}$ & 0 & 0.3 & 0.048 \\
\hline
\end{tabular}

Sumber: Hasil Analisa, 2018

Berdasarkan Tabel 4-5 dijelaskan kalibrasi data dengan mengubah parameter CN2, Surlag, Sol_Awc, Esco, Alpha_Bf, Gw_Delay, Gw_ Revap, Rchrg_dp. Perubahan nilai parameter CN2 pada database ArcSWAT menunjukkan tingginya limpasan permukaan yang terjadi di DAS Lesti. Nilai CN2 menjelaskan tentang kemampuan tanah untuk menyerap serta menyimpan air. Tingginya nilai $C N 2$ atau nilai CN2 menunjukkan nilai maksimal menandakan bahwa kondisi tanah di sub DAS Lesti setelah mengalami berbagai proses gangguan baik secara alami atau manajemen lahan oleh manusia sehingga menurunkan kemampuan tanah dalam menyimpan air. Penurunan nilai CN2 mengakibatkan ketika curah hujan tinggi sebagian besar air hujan akan menjadi limpasan permukaan daripada terserap atau tersimpan ke dalam tanah. Rendahnya nilai Parameter
Sol_Awc menunjukkan rendahnya kemampuan tanah dalam menampung air. Hal terssebut senada dengan proses yang diakibatkan oleh CN2. Rendahnya nilai Alpha_Bf merupakan suatu indikasi tingginya kontribusi aliran dasar dalam mempertahankan volume aliran sungai/alur. Sementara itu rendahnya nilai parameter $G w_{-}$Delay menujukkan kondisi tanah yang pada sebagian wilayah sub DAS Lesti untuk menahan air pada zona perakaran. Semakin berkurangnya vegetasi sehingga kemampuan untuk menahan air di zona perakaran rendah.

\section{Simulasi Setelah Kalibrasi Dengan TGL Tahun 2009}

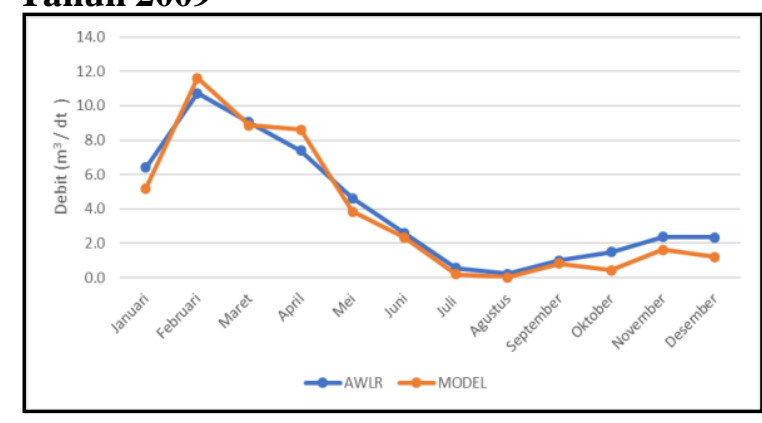

Gambar 5. Grafik hasil simulasi debit ArcSWAT setelah kalibrasi tahun 2009

Sumber: Hasil Analisa, 2018

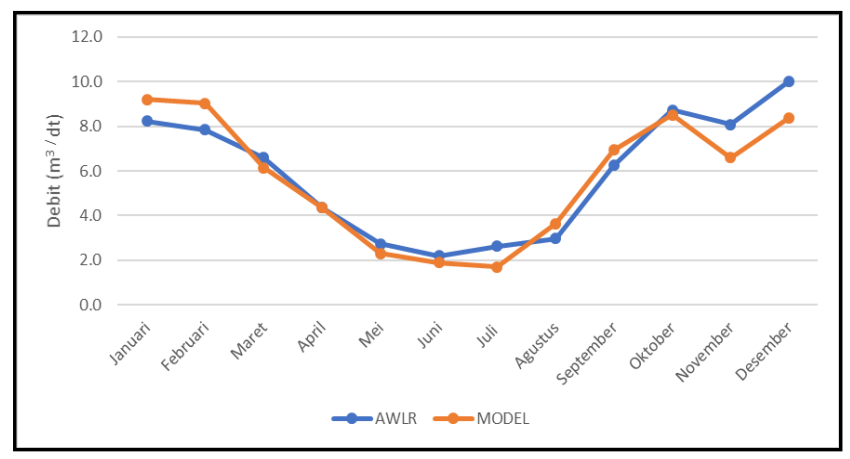

Gambar 6. Grafik hasil simulasi debit ArcSWAT setelah kalibrasi tahun 2016

Sumber: Hasil Analisa, 2018

Pada Tabel 4-5 dan Gambar 5-6 dijelaskan 7 parameter paling sensitif yang telah diubah agar nilai model mendekati nilai lapangan. Dijelaskan hasil simulasi debit setelah dilakukannya kalibrasi data dengan mengubah parameter CN2, Surlag, Sol_Awc, Esco, Alpha_Bf, Gw_Delay, Gw_Revap, Rchrg_dp. Setelah mengubah parameter - parameter tersebut terlihat grafik perbandingan hasil 
model dan lapangan memiliki selisih yang lebih kecil.

\section{Ujian Hasil Simulasi ArcSWAT}

\section{Nash Sutchliffe}

Tabel 6. Rekapitulasi Nilai Uji Nash Sutchliffe

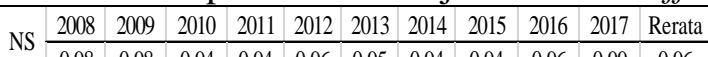

Sumber : Hasil Analisa, 2018

\section{Root Mean Squared Error (RMSE)}

Tabel 7. Rekapitulasi Uji RMSE \begin{tabular}{c|cccccc|ccccc}
\hline \multirow{2}{*}{ RMSE } & 2008 & 2009 & 2010 & 2011 & 2012 & 2013 & 2014 & 2015 & 2016 & 2017 & Rerata \\
\cline { 2 - 10 } & 0.75 & 0.87 & 1.94 & 0.93 & 0.80 & 0.70 & 0.87 & 0.65 & 0.97 & 0.37 & 0.89 \\
\hline
\end{tabular}

Sumber : Hasil Analisa 2018

Dari Tabel 6 - 7 dijelaskan hasil uji model yang dimana terlihat rerata hasil menunjukkan untuk uji Nash Sutchliffe nilai NSE $>0.75$ menunjukkan hasil interpretasi tinggi dan uji RMSE berdasarkan nilai uji RMSE dilihat dari kecilnya hasil uji. Terlihat pada Tabel 7 nilai RMSE tergolong kecil sehingga menunjukkan model baik. Dari kedua uji di atas disimpulkan bahwa model baik.

\section{Hasil Simulasi Nutrien Tahun 2008-2017 Dengan TGL 2009 \\ Nitrat $\left(\mathrm{NO}_{3}\right)$}

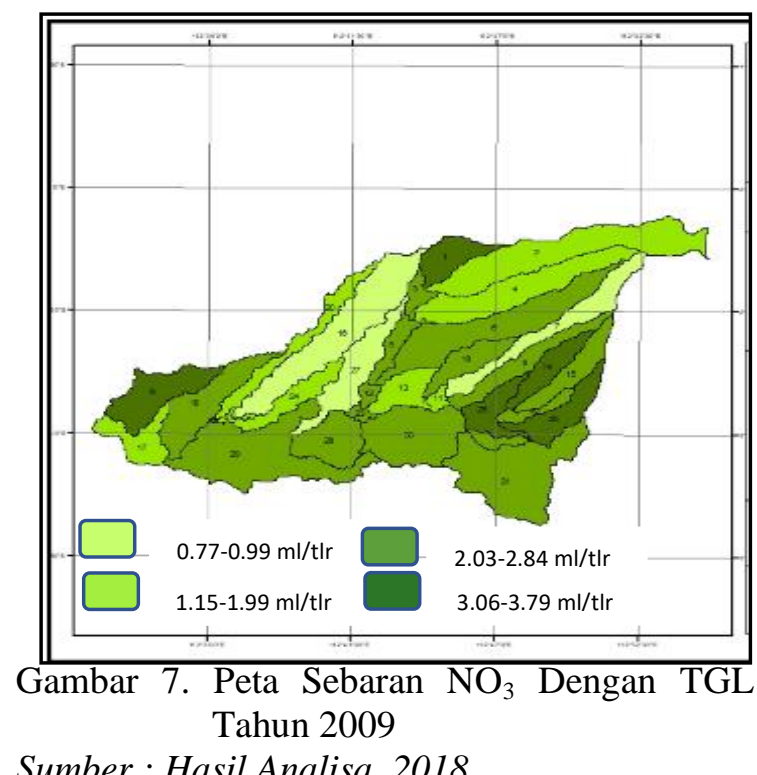

Sumber : Hasil Analisa, 2018

Pada Gambar 7 dijelaskan sebaran $\mathrm{NO}_{3}$ pada sub DAS Lesti tahun 2009. Dari gambar tersebut terlihat bahwa kadar tertinggi terdapat pada Sub DAS 25 sebessar $3.79 \mathrm{mg} / \mathrm{ltr}$ sedangkan terendah pada sub DAS 7 sebesar $0.77 \mathrm{mg} / \mathrm{ltr}$. Tingginya kadar $\mathrm{NO}_{3}$ pada Sub DAS 25 dikarenakan 94.26\% (1361.029 ha) dari tata guna lahan di sub DAS tersebut adalah persawahan, 5. $56 \%$ (80.3118 ha) permukiman dan sisanya hutan dan perkebunan. Kemudian debit pada sub DAS 25 juga kecil sehingga kadar $\mathrm{NO}_{3}$ tidak terencer dengan baik. Area persawahan yang luas diasumsikan memberikan dampak berupa masukan dari penggunaan pupuk pertanian dan debit yang kecil mengakibatkan kadar dari $\mathrm{NO}_{3}$ menjadi tinggi. Untuk kadar $\mathrm{NO}_{3}$ pada Sub DAS 7 yang terendah. Berdasarkan tata guna lahan di sub DAS 7 didominasi kawasan hutan $79.98 \%$ (1683.1308 ha), sawah $15.71 \%$ (330.6455 ha) dan sisanya permukiman dan perkebunan. Debit yang terdapat pada sub DAS 7 sebesar 1031.12 ltr/dtk.

\section{Nitrit $\left(\mathrm{NO}_{2}\right)$}

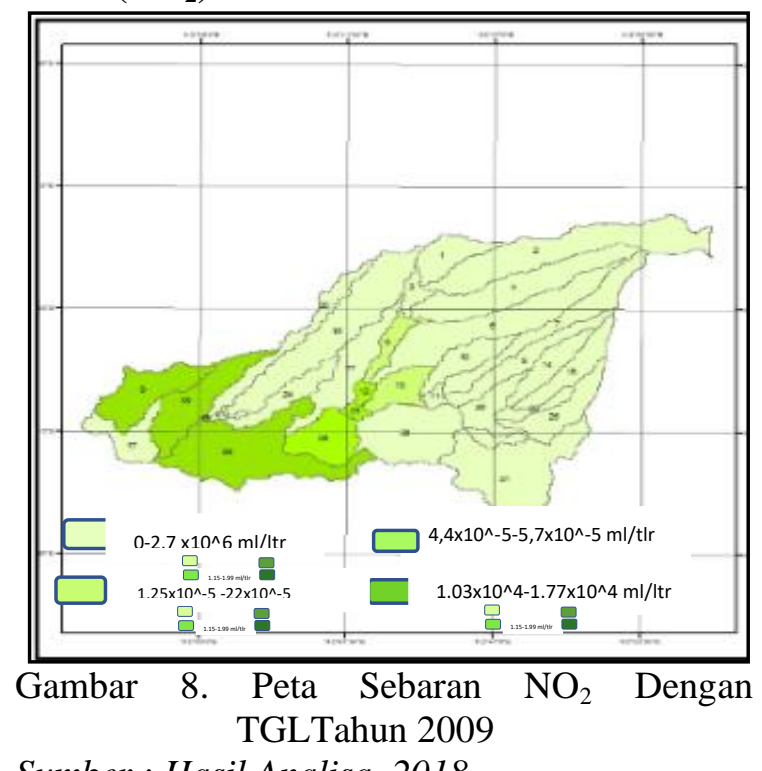

Sumber : Hasil Analisa, 2018

Pada Gambar 8 terlihat sebaran $\mathrm{NO}_{2}$ rerata rendah di sebagian besar wilayah DAS dikarekan $\mathrm{NO}_{2}$ bersifat sementara atau transisi sehingga keberadaannya sedikit. dijelaskan hasil simulasi $\mathrm{NO}_{2}$ di semua sub DAS tahun 2008 - 2017. Dalam simulasi didapatkan nilai $\mathrm{NO}_{2}$ terbesar pada sub DAS 9 dengan kandungan sebesar 1.77 x 10-4 mg/ltr. Sub DAS 9 memiliki Kawasan yang didominasi persawahan seluas 1483.2 ha atau $72.64 \%$ dari luas keseluruhan, kemudian disusul hutan dengan luas 539.114 ha atau $26.40 \%$ dari luas keseluruhan. Sedangkan sisanya terdapat permukiman $0.71 \%$ dan tegalan $0.25 \%$. Kadar $\mathrm{NO}_{2}$ di sub DAS 9 tertinggi dari kadar $\mathrm{NO}_{2}$ di Sub DAS lain disebabkan karena pengaruh dari area persawahan berupa penggunaan pupuk, 
perbandingan antara debit dan kadar $\mathrm{NO}_{2}$ yang besar, dan letak topografi Sub DAS 9 yang berada di Hilir DAS Lesti menjadikannya sebagai akhir distribusi aliran dan $\mathrm{NO}_{2}$. Sedangkan untuk kadar terendah berada pada 20 Sub DAS yang notabene berada pada topografi lebih tinggi atau di Hulu dengan kandungan $\mathrm{NO}_{2}$ sebesar $0 \mathrm{mg} / \mathrm{ltr}$. Sebaran Nutrien sebagaimana terlihat pada Gambar 8 mengarah ke hilir. Sebaran nutrien ke arah hilir disebabkan karena $\mathrm{NO}_{2}$ merupakan bentuk peralihan ke $\mathrm{NH}_{4}$ dan arah aliran ke hilir sehingga dominan $\mathrm{NO}_{2}$ berada di kawasan hilir

\section{Amonium $\left(\mathbf{N H}_{4}\right)$}

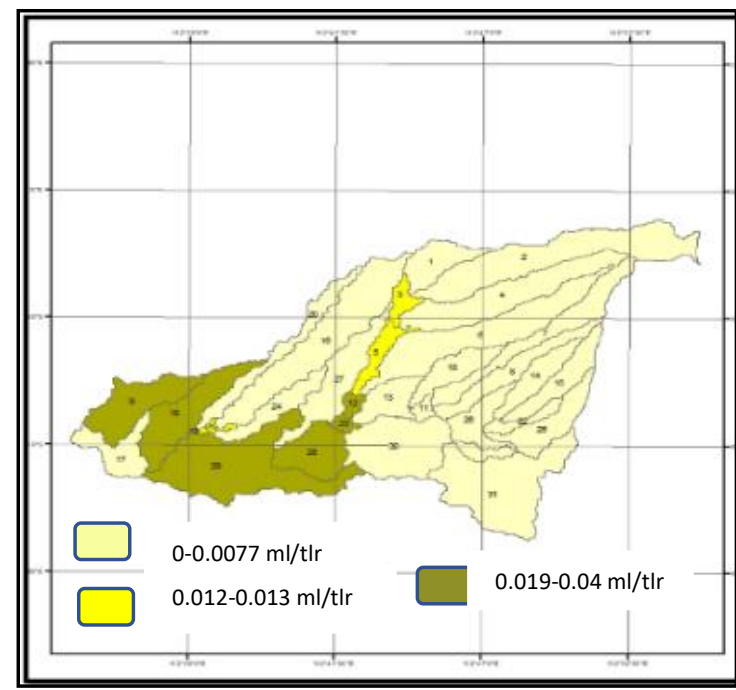

Gambar 9. Peta Sebaran $\mathrm{NH}_{4}$ Dengan TGL Tahun 2009

Sumber : Hasil Analisa, 2018

Pada Gambar 9 terlihat pola sebaran mirip dengan $\mathrm{NO}_{2}$ dimana rerata sebaran banyak terpusat di hilir DAS dikarenakan pengaruh kemiringan dan arah aliran. dijelaskan hasil simulasi $\mathrm{NH}_{4}$ di semua sub DAS tahun 2008 2017. Dalam simulasi didapatkan nilai $\mathrm{NH}_{4}$ terbesar pada sub DAS 9 dengan kandungan sebesar $0.04 \mathrm{mg} / \mathrm{ltr}$. Sub DAS 9 memiliki kawasan yang didominasi persawahan seluas 1483.2 ha atau $72.64 \%$ dari luas keseluruhan, kemudian disusul hutan dengan luas 539.114 ha atau $26.40 \%$ dari luas keseluruhan. Sedangkan sisanya terdapat permukiman $0.71 \%$ dan tegalan $0.25 \%$. Kadar $\mathrm{NH}_{4}$ di sub DAS 9 tertinggi dari kadar $\mathrm{NH}_{4}$ di Sub DAS lain disebabkan karena pengaruh dari area persawahan berupa penggunaan pupuk, perbandingan antara debit dan kadar $\mathrm{NH}_{4}$ yang besar, dan letak topografi Sub DAS 9 yang berada di hilir DAS Lesti menjadikannya sebagai akhir distribusi aliran dan $\mathrm{NO}_{2}$. Sedangkan untuk kadar terendah berada pada 16 Sub DAS yang notabene berada pada topografi lebih tinggi atau di Hulu dengan kandungan $\mathrm{NH}_{4}$ sebesar $0 \mathrm{mg} / \mathrm{ltr}$. Secara garis trend terlihat adanya penurunan kadar $\mathrm{NH}_{4}$ dari tahun 2008 - 2017. Kadar tertinggi berada pada tahun 2014 sebesar $0.038 \mathrm{mg} / \mathrm{ltr}$, sedangkan terendah pada tahun 2010 sebesar $0.009 \mathrm{mg} / \mathrm{ltr}$. Tingginya kadar $\mathrm{NH}_{4}$ pada tahun 2014 terjadi diakibatkan debit tahun 2014 terutama pada bulan Juni- Oktober sangat kecil sehingga debit fungsi debit sebagai pelarut tidak berjalan maksimal. Untuk kadar $\mathrm{NH}_{4}$ memiliki kadar terendah sebesar $0.009 \mathrm{mg} / \mathrm{ltr}$ disebabkan karena debit yang besar terutama pada bulan Januari - April sehingga fungsi debit sebagai pelarut berjalan maksimal.

\section{Total Nitrogen}

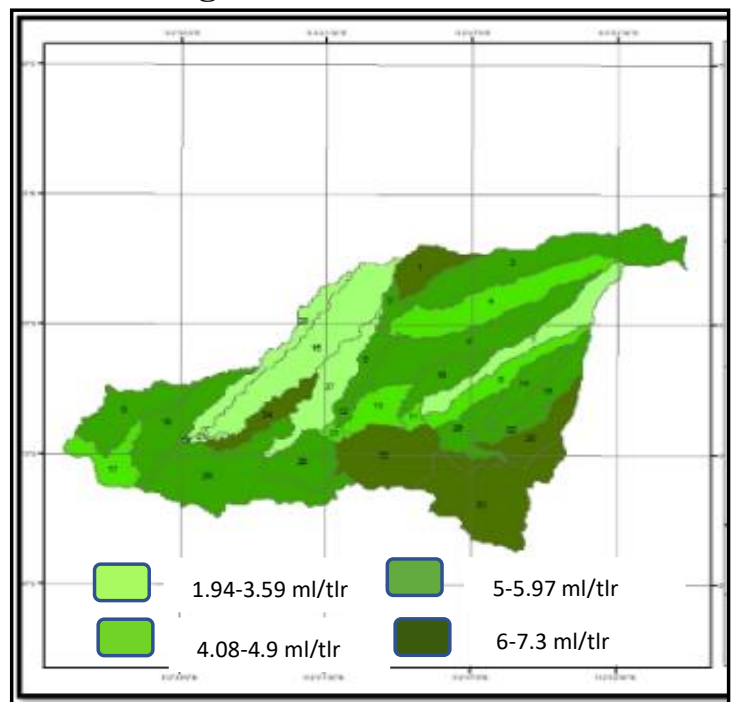

Gambar 10. Peta Sebaran Total Nitrogen Dengan TGL Tahun 2009

Sumber : Hasil Analisa, 2018

Pada Gambar 10 dijelaskan hasil simulasi total nitrogen di semua sub DAS tahun 2008 2017. Dalam simulasi didapatkan nilai Total nitrogen terbesar pada sub DAS 31 dengan kandungan sebesar $7.3 \mathrm{mg} / \mathrm{ltr}$. Sub DAS 31 memiliki kawasan yang didominasi persawahan seluas 3316.16 ha atau $77.89 \%$ dari luas keseluruhan, kemudian disusul permukiman dengan luas 299.033 atau $7.02 \%$ dari luas keseluruhan. Sedangkan sisanya terdapat permukiman $0.71 \%$ dan tegalan $0.25 \%$. Kadar total nitrogen di Sub DAS 31 tertinggi dari kadar total nitrogen di Sub DAS lain disebabkan karena pengaruh dari area persawahan berupa penggunaan pupuk, 
perbandingan antara debit dan kadar Total nitrogen yang besar. Sedangkan untuk kadar terendah berada pada Sub DAS 27 yang memiliki perbandingan debit dan kadar nutrien total nitrogen lebih kecil. Debit pada Sub DAS 27 sebesar 975.5 ltr/dtk dan kadar total nitrogen sebesar 1893.19 dalam mg/dt. Sehingga ketika dikonversi menjadi $\mathrm{mg} / \mathrm{ltr}$ kadar nutrient total nitrogen dalam $\mathrm{mg} / \mathrm{ltr}$ menjadi lebih kecil senilai $1.94 \mathrm{mg} / \mathrm{ltr}$

\section{Total Fosfat}

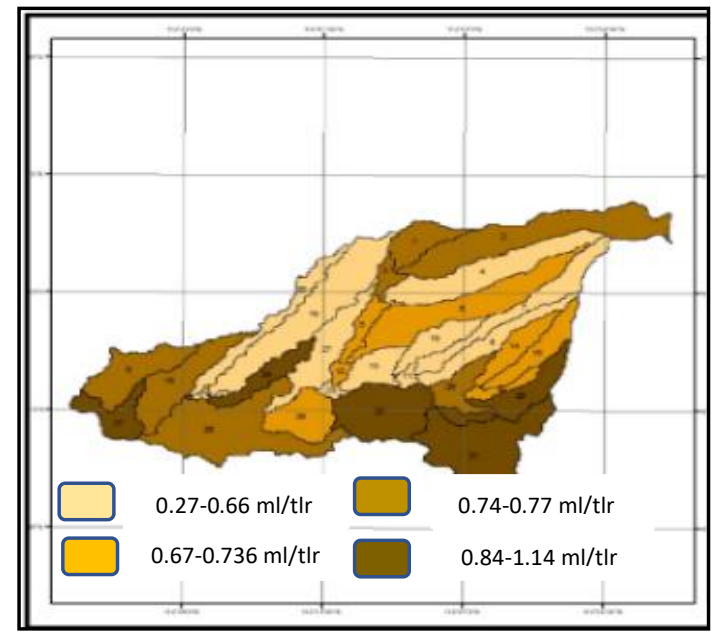

Gambar 11. Peta Sebaran Total Fosfat Dengan TGL Tahun 2009

Sumber : Hasil Analisa, 2018

Pada Gambar 11 atas dijelaskan hasil simulasi total fosfat di semua sub DAS tahun 2008 - 2017. Dalam simulasi didapatkan nilai total fosfat terbesar pada sub DAS 17 dengan kandungan sebesar $1.14 \mathrm{mg} / \mathrm{ltr}$. Sub DAS 17 memiliki kawasan yang didominasi persawahan seluas 952.635 ha atau $78.89 \%$ dari luas keseluruhan 2997.93 ha, Sedangkan sisanya terdapat permukiman $21.48 \%$ atau 260.58 ha. Kadar total fosfat di sub DAS 17 tertinggi dari kadar total fosfat di Sub DAS lain disebabkan karena pengaruh dari area persawahan berupa penggunaan pupuk, perbandingan antara debit dan kadar Total fosfat yang besar. Sedangkan untuk kadar terendah berada pada Sub DAS 27 yang memiliki perbandingan debit dan kadar nutrien total fosfat lebih kecil. Debit pada Sub DAS 27 sebesar 574.77 ltr/dtk dan kadar total fosfat sebesar 580.54 dalam $\mathrm{mg} / \mathrm{dt}$. Sehingga ketika dikonversi menjadi $\mathrm{mg} / \mathrm{ltr}$ kadar nutrient total fosfat dalam $\mathrm{mg} / \mathrm{ltr}$ menjadi lebih kecil senilai $0.27 \mathrm{mg} / \mathrm{ltr}$.

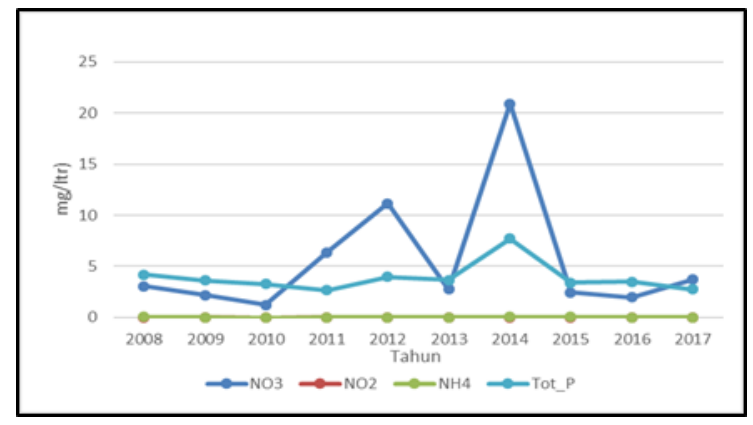

Gambar 12. Peta Sebaran $\mathrm{NO}_{3}, \mathrm{NO}_{2}$, Total Fosfat Tahun 2008-2017

Sumber : Hasil Analisa, 2018

Dari Gambar 12 terlihat grafik kadar $\mathrm{NO}_{3}, \quad \mathrm{NO}_{2}$, total fosfat Tahun 2008-2017 bersifat fluktuatif. Secara rerata nutrien tinggi mulai tahun 2011 berakhir tahun 2015 dikarenakan curah hujan lebih rendah.

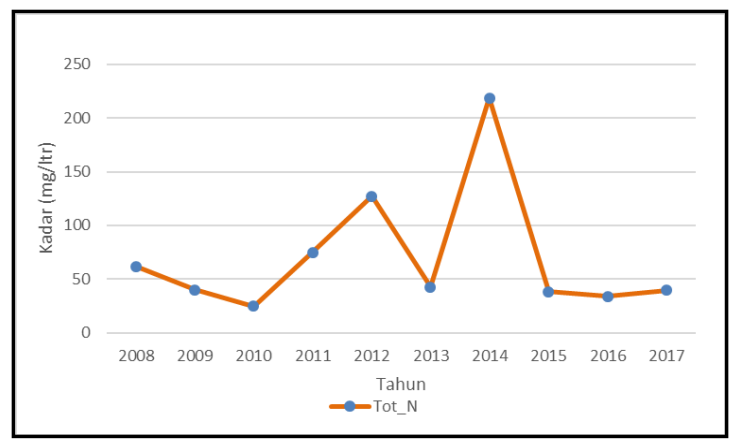

Gambar 13. Peta Sebaran Total Nitrogen Tahun 2008-2017

Sumber : Hasil Analisa, 2018

Pada Gambar 13 terlihat grafik total nitrogen yang fluktuatif dan tergolong kadar tertinggi dari kadar nutrient lainnya dikarenakan sumber dari total nitrogen terbesar di Biosfer. Secara garis trend terlihat adanya peningkatan kadar $\mathrm{NO}_{3}$ dari tahun 2008 - 2017. Kadar tertinggi berada pada tahun 2014 sebesar 20.934 (mg/ltr), sedangkan terendah pada tahun 2010 sebesar $1.20(\mathrm{mg} / \mathrm{ltr})$. Tingginya kadar $\mathrm{NO}_{3}$ pada tahun 2014 terjadi diakibatkan debit tahun 2014 terutama pada bulan kering (Juni, Juli, Agustus).

Sangat kecil sehingga debit fungsi debit sebagai pelarut tidak berjalan maksimal. Secara garis trend terlihat adanya penurunan kadar $\mathrm{NO}_{2}$ dari tahun 2008 - 2017. Kadar tertinggi berada pada tahun 2011 sebesar 0.000818 (mg/ltr), sedangkan terendah pada tahun 2010 sebesar 1,0 x 10-5 (mg/ltr). Tingginya kadar $\mathrm{NO}_{2}$ pada tahun 2011 terjadi pada bulan 
Februari dengan debit $5.22 \mathrm{mg} / \mathrm{dtk}$ dan kadar $\mathrm{NO}_{2}$ sebesar $461.843 \mathrm{mg} / \mathrm{dtk}$.

Kecilnya debit pada Bulan Februari dan besarnya kadar $\mathrm{NO}_{2}$ menyebabkan debit tidak mampu meng- encerkan nutrient dengan baik, serupa juga terjadi pada Bulan Juli dan Agustus. Secara garis trend terlihat adanya penurunan kadar $\mathrm{NH}_{4}$ dari tahun 2008 - 2017. Kadar tertinggi berada pada tahun 2014 sebesar $0.038 \mathrm{mg} / \mathrm{ltr}$, sedangkan terendah pada tahun 2010 sebesar $0.009 \mathrm{mg} / \mathrm{ltr}$. Secara garis trend terlihat adanya peningkatan kadar Tot_P dari tahun 2008 - 2017. Kadar tertinggi berada pada tahun 2014 sebesar $7.72 \mathrm{mg} / \mathrm{ltr}$, sedangkan terendah pada tahun 2011 sebesar $2.65 \mathrm{mg} / \mathrm{ltr}$.

Analisa Status Mutu 2008-2017

Tabel 8. Penentuan Status Mutu Tahun 2008-

\begin{tabular}{|c|c|c|c|c|c|c|}
\hline \multirow{2}{*}{ Parameter } & \multicolumn{6}{|c|}{ Hasil Model } \\
\hline & Satuan & $\begin{array}{l}\text { Baku } \\
\text { Mutu }\end{array}$ & Maks & Min & Rerata & Skor \\
\hline $\mathrm{NO} 2$ & $(\mathrm{mg} / \mathrm{t})$ & 0.06 & 0.00818 & 0.00001 & 0.00209 & 0 \\
\hline$\underset{N}{\mathrm{NO} 3 \text { Sebagai }}$ & $(\mathrm{mg} / \mathrm{tt})$ & 10 & 20.9338 & 1.20406 & 5.579150 & 2 \\
\hline $\begin{array}{c}\text { Total Fosfat } \\
\text { Sebagai P }\end{array}$ & $(\mathrm{mg} / \mathrm{lt})$ & 0.2 & 7.7203 & 2.64795 & 3.86862 & 10 \\
\hline \multicolumn{6}{|c|}{ Jumlah Skor } & 12 \\
\hline \multirow{2}{*}{\multicolumn{6}{|c|}{ Keterangan }} & Kelas C \\
\hline & & & & & & $\begin{array}{r}\text { Tercemar } \\
\text { Sedang }\end{array}$ \\
\hline
\end{tabular}

Sumber : Hasil Analisa, 2018

Pada Tabel 8 disimpulkan bahwa status mutu yaitu kelas $\mathrm{C}$ dengan kondisi tercemar sedang. Tingginya total fosfat disebabkan pengaruh dari pupuk pada kawasan pertanian serta perbandingan kadar total fosfat yang jauh lebih besar dari debitnya sehingga tak mampu melarutkan nutrient.

\section{Analisa Status Trofik Tahun 2008-2017}

Analisa status trofik untuk setiap sub DAS. Dari hasil Analisa status trofik untuk setiap sub DAS. Dari hasil simulasi diperoleh sejumlah nilai kandungan total fosfat dan nitrogen yang kemudian dikonversikan satuannya menjadi $\mu \mathrm{g} /$ ltr. Berdasarkan Tabel pada PerMNLH Nomor 28 tahun 2009, maka hasil konversi Tot_P dalam $\mu \mathrm{g} / \mathrm{ltr}$ disesuai- kan dengan klasifikasi status trofik dalam PerMNLH Nomor 28 tahun 2009 dan didapatkan stats trofik rerata untuk keseluruhan sub DAS ialah oligotrofik atau masih termasuk rendah.
Hasil Simulasi Nutrien tahun 2018-2027 Dengan TGL 2016

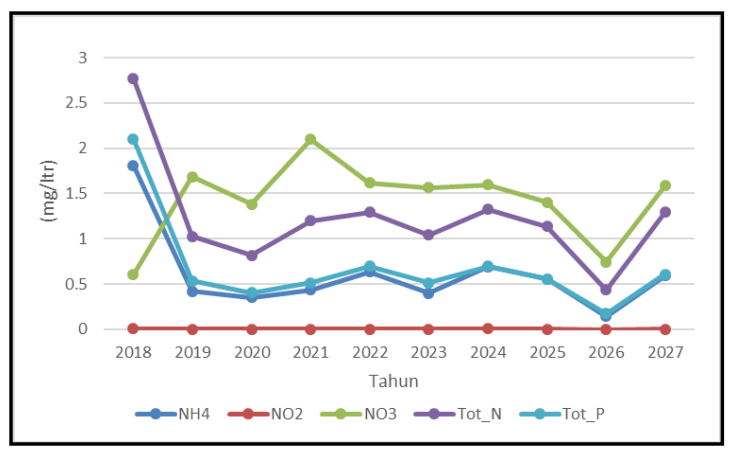

Gambar 14. Peta Sebaran $\mathrm{NH}_{4}, \mathrm{NO}_{2}, \mathrm{NO}_{3}$, Total Fosfat, Total Nitrogen Tahun 2018-2027 Sumber : Hasil Analisa, 2018

Dari Gambar 14 terlihat grafik nutrien berdasarkan simulasi tahun 2018-2027 dengan TGL 2016. Terlihat grafik berfluktuatif dan kadar nutrient lebih besar dari simulasi pertama dikarenakan adanya perubahan tataguna lahan sehingga meningkatkan degradasi lingkungan sub DAS.

Status Mutu Hasil Model Tahun 2018-2027

Tabel 9. Analisa Status Mutu Model Tahun 2018-2027

\begin{tabular}{|c|c|c|c|c|c|c|}
\hline \multirow{2}{*}{ Parameter } & \multicolumn{6}{|c|}{ Hasil Model } \\
\hline & Satuan & $\begin{array}{l}\text { Baku } \\
\text { Mutu }\end{array}$ & Maks & Min & Rerata & Skor \\
\hline $\mathrm{NO}_{2}$ & $(\mathrm{mg} / \mathrm{lt})$ & 0.06 & 0.0 & 0.0 & 0.0 & 0 \\
\hline $\mathrm{NO}_{3}$ Sebagai $\mathrm{N}$ & (mg/lt) & 10 & 2.1 & 0.6 & 1.4 & 0 \\
\hline $\begin{array}{l}\text { Total Fosfat } \\
\text { Sebagai P }\end{array}$ & $(\mathrm{mg} / \mathrm{lt})$ & 0.2 & 0.9 & 0.1 & 0.3 & 8 \\
\hline \multicolumn{6}{|c|}{ Jumlah Skor } & 8 \\
\hline \multirow{2}{*}{\multicolumn{6}{|c|}{ Keterangan }} & Kelas B \\
\hline & & & & & & $\begin{array}{c}\text { Tercemar } \\
\text { Ringan }\end{array}$ \\
\hline
\end{tabular}

Sumber : Hasil Analisa, 2018

Pada Tabel 9 disimpulkan bahwa status mutu yaitu kelas B dengan kondisi tercemar ringan. Tingginya total fosfat disebabkan pengaruh dari pupuk pada kawasan pertanian serta perbandingan kadar total fosfat yang jauh lebih besar dari debitnya sehingga tak mampu melarutkan nutrient. Namun Lebih rendah dari simulasi pertama.

\section{Analisa Status Trofik Tahun 2018-2027}

Hasil analisa status trofik berdasarkan nilai simulasi total nitrogen dan total fosfat. Dari hasil simulasi kemudian dikonversikan kedalam satuan $\mu \mathrm{g} / \mathrm{ltr}$ disesuaikan dengan nilai klasifikasi status trofik pada Peraturan Menteri Lingkungan Hidup Nomor 28 tahun 2009 
terlihat rerata tergolong didominasi oleh status hipereutrofik atau tergolong tinggi.

\section{Analisa Strategi Prioritas Metode AHP}

Analisa AHP dilakukan untuk menganalisa strategi prioritas dari strategi-strategi berikut ini :

$>$ Meningkatkan inventarisasi dan identifikasi sumber pencemar air (A)

$>$ Meningkatkan kuantitas dan kualitas IPAL (B)

$>$ Menetapkan daya tampung dan beban pencemaran $(\mathbf{C})$

$>$ Pengetahuan dan penerapan konsep partisipasi bagi masyarakat dalam pelaksanaan kegiatan pengendalian pencemaran air dan pengelolaan limbah (D)

$>$ Meningkatkan pengawasan terhadap pembuangan air limbah $(\mathbf{E})$

$>$ Meningkatkan pemantauan kualitas air sungai $(\mathbf{F})$

$>$ Pengendalian dan sosialisasi penggunaan pupuk serta pestisida bagi petani $(\mathbf{G})$

$>$ Pengendalian alihfungsi lahan daerah hulu DAS (H)

Dari hasil pengisian kuisioer oleh responden kemudian data dianalisa dan direkapitulasi sesuai pada Tabel 10.

Tabel 10. Rerata Priority Vector dan Peringkatnya Berdasarkan Data BPDAS, PUSDA, Dan DLH

\begin{tabular}{|c|c|c|c|c|c|}
\hline \multirow{2}{*}{ Strategi } & \multicolumn{3}{|c|}{ Priority Vector } & \multirow{2}{*}{ Rerata } & \multirow{2}{*}{ Peringkat } \\
\hline & BPDAS & PUSDA & DLH & & \\
\hline A & 0.227 & 0.282 & 0.211 & 0.240 & 1 \\
\hline B & 0.151 & 0.075 & 0.169 & 0.132 & 4 \\
\hline $\mathrm{C}$ & 0.136 & 0.167 & 0.169 & 0.158 & 3 \\
\hline $\mathrm{D}$ & 0.200 & 0.184 & 0.142 & 0.175 & 2 \\
\hline E & 0.117 & 0.120 & 0.099 & 0.112 & 5 \\
\hline $\mathrm{F}$ & 0.071 & 0.084 & 0.081 & 0.079 & 6 \\
\hline G & 0.053 & 0.034 & 0.079 & 0.056 & 7 \\
\hline $\mathrm{H}$ & 0.043 & 0.053 & 0.050 & 0.049 & 8 \\
\hline
\end{tabular}

Sumber : Hasil Analisa, 2018

Dari Tabel 10 berdasarkan analisa strategi prioritas metode AHP diperoleh simpulan bahwa strategi peringkat pertama ialah strategi A yaitu meningkatkan inventarisasi dan identifikasi sumber pencemaran.

\section{KESIMPULAN DAN SARAN}

Dalam analisis dan pemodelan kualitas air di Sub DAS Lesti untuk tahun 2008-2017 dengan menggunakan tata guna lahan tahun 2009 diperoleh kadar nutrien dengan status mutu kelas $\mathrm{C}$ yaitu tercemar sedang dan rerata status trofiknya oligotrofik, dan pemodelan dengan tata guna lahan 2016 untuk tahun 20182027 menunjukkan kelas B yaitu tercemar ringan namun rerata status trofiknya hipereutrofik. Berdasarkan hasil metode AHP untuk kelima responden di tiga instansi yakni Balai Pengelolaan Daerah Aliran Sungai Brantas, Dinas Lingkungan Hidup Kabupaten Malang, dan Dinas Pekerjaaan Umum Sumber Daya Air disimpulkan bahwa strategi A yakni meningkatkan inventarisasi dan identifikasi sumber pencemar air sebagai strategi prioritas. Strategi ini dapat menjadi masukan bagi instansi terkait konservasi lingkungan di Jawa Timur khususnya Kabupaten Malang.

\section{DAFTAR PUSTAKA}

Arbi, Leo Rizky. (2007). Pengaruh Perubahan Tata Guna Lahan Terhadap Kualitas Air Sungai Lesti. Skripsi. Tidak Dipublikasikan. Malang. Universitas Brawijaya.

Cesar Perez-Valdivia, Barbara Cade-Menun, Dena W. McMartin. (2017). Hydrological modeling of the pipestone creek watershed using the Soil Water Assessment Tool (SWAT): Assessing impacts of wetland drainage on hydrology. Journal of Hydrology: Regional Studies, Volume 14, December 2017, Pages 109-129.

Cheng-Zhi Qin, Bei-Bei Ai, A-Xing Zhu, JunZhi Liu. (2017). An efficient method for applying a differential equation to deriving the spatial distribution of specific catchment area from gridded digital elevation models. Computers \& Geosciences, Volume 100, March 2017, Pages 94-102.

Effendi, Hafni. (2003). Telaah Kualitas Air Bagi Pengelolaan Sumber Daya dan Lingkungan Perairan.Yogyakarta : PT. Kanisius.

Hidayat, L. Sudira, P. Susanto, S. Jayadi, R. (2016). Validasi Model Hidrologi SWAT di Daerah Tangkapan Air Waduk Mrica. Agritech. Vol. 4 : 467-474.

Kementerian Lingkungan Hidup. (2003). Pedoman Penentuan Status Mutu Air. Jakarta. Kementerian Lingkungan Hidup. 
Kementerian Lingkungan Hidup. (2009). Daya Tampung Beban Pencemaran Ir Danau Dan/Atau Waduk. Jakarta. Kementerian Lingkungan Hidup.

Kementerian Lingkungan Hidup. (2010). Pengelolaan Kualitas Air dan Pengendalian Pencemaran Air. Kementerian Lingkungan Hidup.

Riyanto Haribowo, Minami Yoshimura, Masahiko Sekine, Tsuyoshi Imai, Koichi Yamamoto, Takaya Higuchi, Ariyo Kanno. (2017). Behavior of toxicity in river basins dominated by residential areas. Contemporary Engineering Sciences 10 (7), 305-315.

Saaty, Thomas Lorrie. (1993). Pengambilan Keputusan Bagi Para Pemimpin, Proses Hirarki Analitik untuk Pengambilan Keputusan dalam Situasi yang Kompleks. Setiono L, penerjemah; Peniwati K, editor. Jakarta: PT.Pustaka Binaman Pressindo. Terjemahan dari: Decision Making for
Leaders The Analytical Hierarchy Process for Decisions in Complex World.

Soewarno. (1996). Hidrologi, Aplikasi Metode Statistik Untuk Analisis Data. Bandung. Penerbit Nova.

Suhartanto, Ery. (2008). Panduan Aplikasi AVSWAT 2000. Malang : CV. Asrori Malang

Urooj Khan, Narendra Kumar Tuteja, Ashish Sharma. (2013). Delineating hydrologic response units in large upland catchments and its evaluation using soil moisture simulations. Environmental Modelling \& Software, Volume 46, August 2013, Pages 142-154.

Yamashita H, Haribowo R, Sekine M, Oda N, Kanno A, Shimono Y, Shitao W, Higuchi T, Imai T, Yamamoto K. (2012). Toxicity test using medaka (Oryzias latipes) early fry and concentrated sample water as an index of aquatic habitat condition. Environmental Science and Pollution Research 19 (7), 2581-2594. 